\title{
Intergeneric Hybridization between Raphanus sativus L. and Brassica nigra Косн. and Alloplasmic Radish Derivative
}

\author{
Yasuo Matsuzawa and Masao Sarashima \\ Faculty of Agriculture, Utsunomiya University, Utsunomiya, $\bar{T} 321$
}

\begin{abstract}
Cytological and morphological observations were made on the intergeneric new hybrids between Raphanus sativus and Brassica nigra and the derived progenies. Chromosomes of $F_{1}$ hybrids in the meiosis of the pollen mother cells (PMC) were amphihaploid except for an amphidiploid plant $\left(\mathrm{NiR} \mathrm{F}_{1}-3\right)$ in B. nigra $\times$ R. sativus. Amphihaploids showed the pairing type of $(0-4) I I+(9-17)$ I at metaphase I (MI) and the chromosome number of most of the PMCs at metaphase II (MII) ranged from 5 to 12 with a modal value of 8 or 9 . An amphidiploid plant showed a relatively regular meiosis with $17 \mathrm{II}$ at MI and PMCs with 17 chromosomes at MII. The morphology of the amphihaploids was intermediate between that of the parent cultivars except for the presence of white flowers. Due to the meiotic abnormalities, amphihaploids failed to produce viable pollen and seed. An amphidiploid of $\mathrm{NiR}_{\mathrm{F}_{1}-3}$ was very large and showed seed fertility. Backcrossed generations with $R$. sativus and B. nigra were sesquidiploids of BRR $(2 n=26)$ and BBR $(2 n=25)$ showing pairing types of $9 \mathrm{II}+8 \mathrm{I}$ and $8 I I+9 I$ at MI, respectively. The BRR plants preserved their seed fertility not only in open pollination but in further backcrossing to two cultivars of $R$. sativus. Derived plants were euploid $(2 n=18)$ or hyperploid $(2 n=19-22)$. Prevailing occurrence of univalents and bivalents in both amphiploids and derived progenies suggested the occurrence of more frequent autosyndetic pairings than allosyndetic ones at MI. Subsequently new alloplasmic radish lines, viz. R. sativus with B. nigra cytoplasm were bred. These lines produced fertile seeds in the next backcrossing to $R$. sativus.
\end{abstract}

KEY WORDS : Raphanus sativus, Brassica nigra, embryo and ovary culture, intergeneric hybrids, alloplasmic radish.

\section{Introduction}

Among the cultivated Brassica crops, B.campestris $(n=10)$, B. nigra $(n=8)$ and B. oleracea $(n=9)$ are recognized to be the donors of $\mathrm{A}, \mathrm{B}$ and $\mathrm{C}$ genomes, respectively. Intergeneric hybridization between Raphanus sativus ( $n=9, \mathrm{R}$ genome) and these Brassica species has been carried out by many workers and reviewed by HARBERD and McArthur (1980). It was demonstrated that hybridization was more successful between $R$. sativus $\times$ B. oleracea and B. campestris $\times R$. sativus. These hybrids were named Raphanobrassica (Karpechenko 1927) and Brassicoraphanus (Terasawa and Shimotomai 1928, Tokumasu 1976), respectively. Sarashima et al. (1980) produced another Brassicoraphanus between $B$.oleracea $\times R$. sativus by means of embryo culture in vitro.

However, as far as we know, reciprocal hybrids between $R$. sativus and B.nigra have not yet been obtained. In this report the new hybrid plants and their progenies are described from the view point of breeding alloplasmic lines of radish.

\section{Materials and Methods}

Plant materials used in this study are intergeneric $\mathrm{F}_{1}$ hybrids between $R$. sativus $\times B$. nigra which were obtained previously by means of embryo culture (MATsuzAwA 1983). Other hybrid plants between $B$. nigra $\times$ R. sativus were produced by ovary culture according

Received August 6, 1985. 
to the method of Inomataa (1977); namely young ovaries were cultured on the $0.8 \%$ agar medium of White (1963) supplemented with $0.5 \mathrm{~g} / l$ casein hydrolysate and $30 \mathrm{~g} / l$ sucrose 7 days after pollination. Ovaries were cultured at ca. $25^{\circ} \mathrm{C}$ for 60 days, the resulting hybrid embryos were excised and immediately cultured on the same medium at $15^{\circ} \mathrm{C}$. Hybrid plants thus obtained were carefully potted and nursed at $15^{\circ} \mathrm{C}$ for 5 weeks to avoid a spindy shape. Bud pollination was predominantly adopted to obtain the following hybrid progenies.

Somatic chromosomes were observed in root tips which were pretreated with $0.002 \mathrm{M}$ 8-hydroxyquinoline for $3 \mathrm{hrs}$ and fixed in Farmer's fluid overnight. Fixed materials were hydrolyzed in $1 \mathrm{~N} \mathrm{HCl}$ at $60^{\circ} \mathrm{C}$ for 6 minutes and then stained in Shiff's reagent for $4 \mathrm{hrs}$. Root tips were further stained in a drop of acetocarmine on the slides and squashed strongly. For meiotic analysis, pollen mother cells (PMC) were squashed with a coverslip after immersion in acetocarmine and then the slides were warmed gently, followed by sealing with paraffine.

\section{Results}

As shown in Table 1, seven new hybrid plants were grown in four cross combinations. They showed the putative sum of gametic chromosomes of their parents, except for NiR $F_{1}-3$ which had 34 chromosomes $(2 n)$ suggesting the presence of the amphidiploid genome constitution of BBRR. RNi $F_{1}$ plants had a compound raceme with white flowers bearing a slight resemblance to those of $R$. sativus. The leaf shape and flower size were intermediate between those of parent cultivars. NiR $F_{1}$ hybrids showed a similar morphology to that of reciprocal hybrids except for the relatively tall raceme (Fig. 1 A). An amphidiploid hybrid was very large especially with giant flowers more or less yellowish white in color (Fig. $1 \mathrm{~B}$ ).

Meiosis in the PMCs is described in Table 2. Amphihaplid hybrids exhibited the pairing type of (0-4)II+(9-17) I at metaphase $I(M I)$, and more than $80 \%$ of the PMCs exhibited no pairing or one at most. Most of the nuclear plates of PMCs showed a number of chromosomes ranging from 5 to 12 at metaphase $\mathbb{I}$ (MII), although cells with 8 or 9 chromosomes were more frequent. PMCs with a $2 I I+13$ I configuration at $\mathrm{MI}$ and distribution of 17 chromosomes at $\mathrm{MII}$ are shown in Fig. $1 \mathrm{C}$ and Fig. $1 \mathrm{D}$, respectively. These amphihaploid hybrids did not produce pollen that could be stained by acetocarmine, nor did they develop pods in backcrossing to the parental cultivars

Table 1. Intergeneric amphiploids between $R$. sativus and B. nigra

\begin{tabular}{|c|c|c|c|c|}
\hline \multirow{2}{*}{ Hybrids } & \multicolumn{2}{|c|}{ Cross combination } & \multirow{2}{*}{$\begin{array}{l}\text { Somatic } \\
\text { chromosomes }\end{array}$} & \multirow{2}{*}{$\begin{array}{l}\text { Genome } \\
\text { constitution }\end{array}$} \\
\hline & Female & Male & & \\
\hline RNi $F_{1}-1$ & Shirokubi-nagashiri & $\mathrm{Ni} 110$ & $2 n=17$ & $\mathrm{RB}$ \\
\hline $\mathrm{RNi} \mathrm{F}_{1}-2$ & ditto & ditto & $2 n=17$ & $\mathrm{RB}$ \\
\hline $\mathrm{RNi} \mathrm{F}_{1}-3$ & Horyo & ditto & $2 n=17$ & $\mathrm{RB}$ \\
\hline $\mathrm{NiR} \mathrm{F}_{1}-1$ & $\mathrm{Ni} 110$ & Aokubi-miyashige & $2 n=17$ & $\mathrm{BR}$ \\
\hline $\mathrm{NiR} \cdot \mathrm{F}_{1}-2$ & ditto & ditto & $2 n=17$ & $\mathrm{BR}$ \\
\hline $\mathrm{NiR} \mathrm{F}_{1}-3$ & ditto & ditto & $2 n=34$ & BBRR \\
\hline $\mathrm{NiR} \mathrm{F}_{1}-4$ & ditto & Shogoin & $2 n=17$ & $\mathrm{BR}$ \\
\hline
\end{tabular}



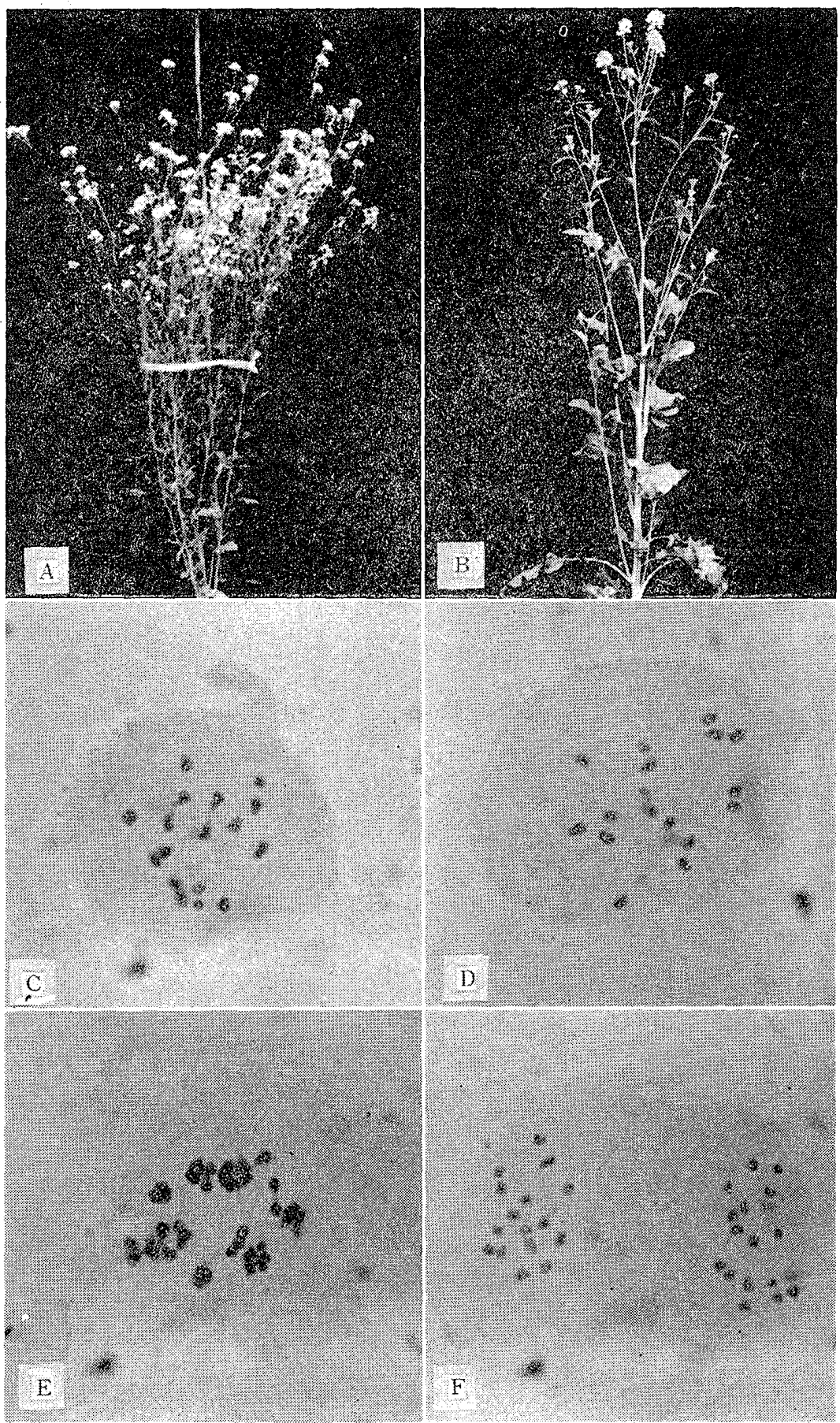

Fig. 1. Intergeneric hybrids between Raphanus satiwus and Brassica nigra.

A : Amphihaploid plant of B. nigra $\times$ R. sativus $\left(\mathrm{NiR}_{1}-2\right.$, $2 n=17), \quad B:$ An amphidiploid plant of B. nigra $\times$ R. sativus (NiR $\left.\mathrm{F}_{1}-3,2 n=34\right), \mathrm{C}: \mathrm{A}$ pollen mother cell at $\mathrm{MI}$ in $\mathrm{NiR}$ $\mathrm{F}_{1}-2$, two bivalents and 13 univalents are observed, D : A pollen mother cell at $\mathrm{MII}$ in NiR $\mathrm{F}_{1}-2$, distribution of 17 chromosomes is recognized, E: A pollen mother cell at MI in $\mathrm{NiR} \mathrm{F}_{1}-3,17$ bivalents are observed, $\mathrm{F}: \mathrm{A}$ pollen mother cell atMII in NiR $F_{1}-3$, pollen mother cell with $17+17 \mathrm{ch}-$ romosomes is recognized. 


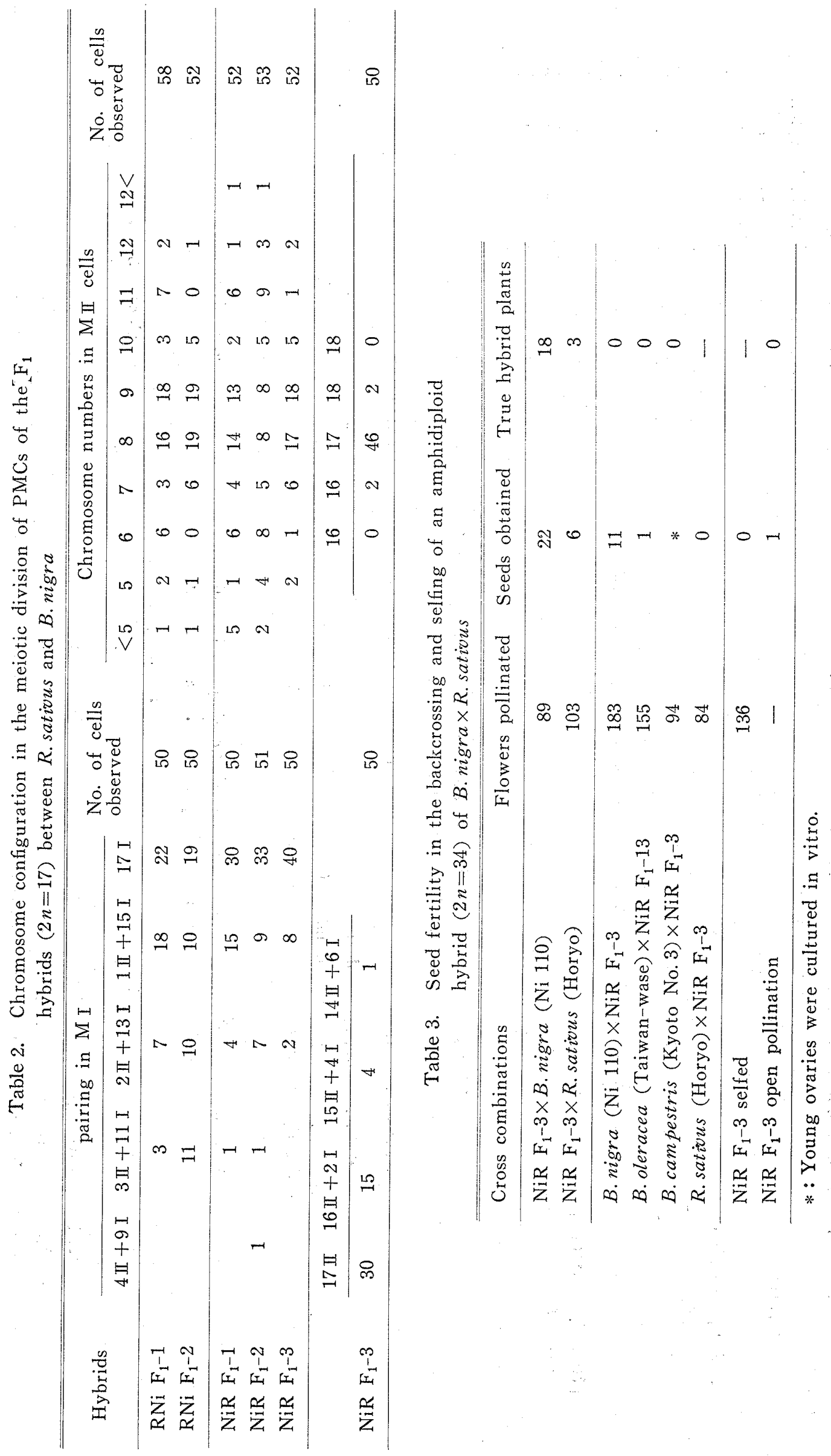




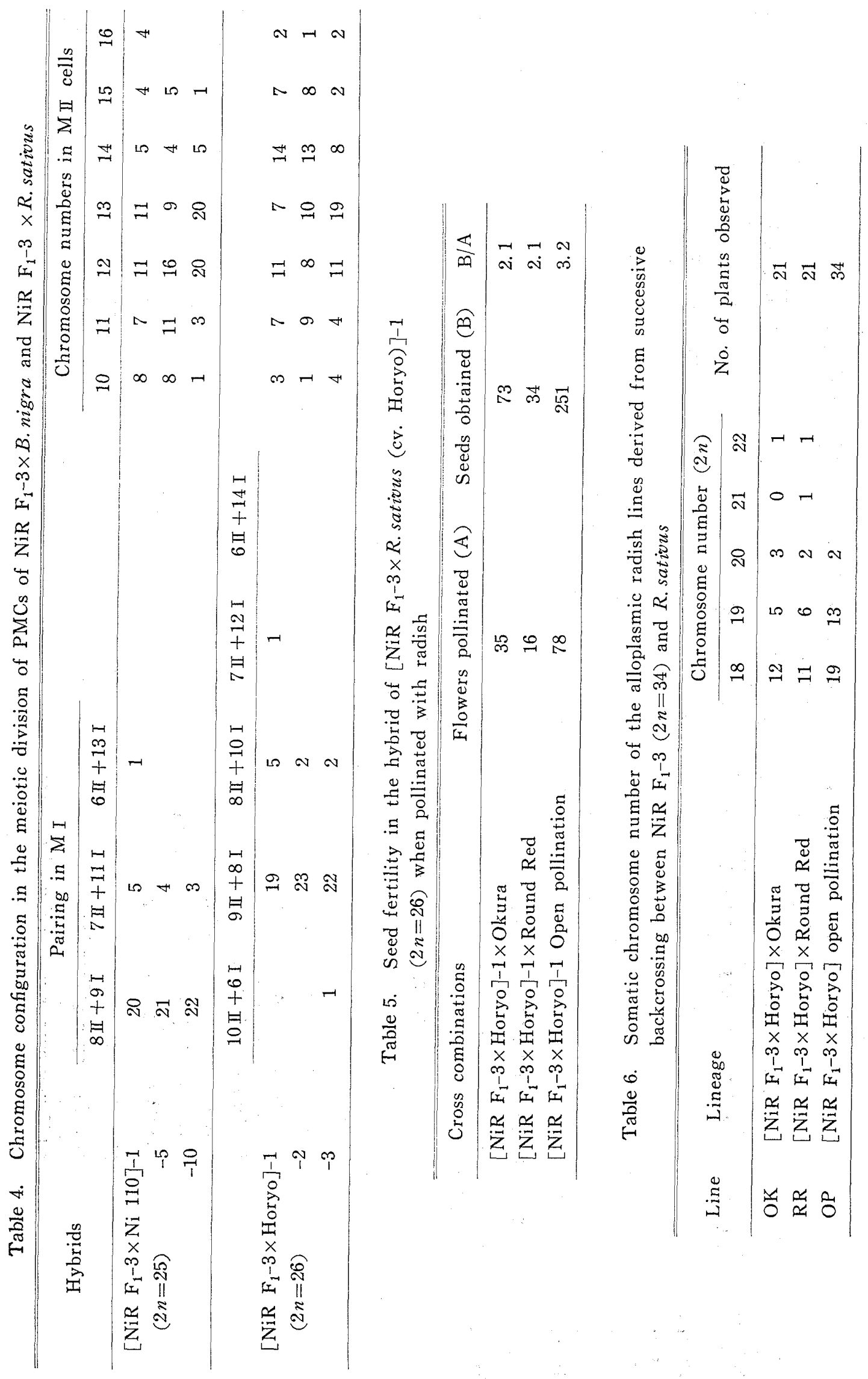


or in open pollination. As a result the hybrids could not be reared for the following generation. An amphidiploid hybrid of $\mathrm{NiR} \mathrm{F}_{1}-3$, on the other hand, showed a relatively regular meiotic behavior with 17 bivalents at $\mathrm{MI}$ and 17-17 distribution type at $\mathrm{MII}$ (Fig. $1 \mathrm{E}$ and Fig. 1F) and produced pollen grains that could be stained.

Pollination was carried out in $\mathrm{NiR} \cdot \mathrm{F}_{1}-3$ used as pistil and pollen parents. As a result, 18 and 3 backcrossed hybrids were obtained between NiR $F_{1}-3 \times$ B. nigra and NiR $F_{1}-3 \times R$. sativus, respectively (Table 3 ). Table 4 shows the meiosis in three plants of both crosses. All of them were confirmed to be sesquidiploids of $\operatorname{BBR}(2 n=25)$ or BRR $(2 n=26)$ in their genome constitution. Two plants in the former cross were hyperploids $(2 n=26)$ which were not listed in Table 4 . Hybrid plants between $\mathrm{NiR} \mathrm{F}_{1}-3 \times$ B.nigra and $\mathrm{NiR} \mathrm{F}_{1}-3 \times$ R. sativus showed the most frequent pairing types of $8 I I+9 \mathrm{I}$ and $9 I I+8 I$, respectively. Nuclear plates at $M I I$ had 10 to 16 chromosomes with a mode of 12,13 or 14 chromosomes. The pollen of the hybrids between NiR $\mathrm{F}_{1}-3 \times B$. nigra was sterile and they did not produce any seed when crossed to cultivars or lines of $R$. sativus and B. nigra, although a few seeds were obtained in open pollination.

$\mathrm{NiR} \mathrm{F}_{1}-3 \times R$. sativus, on the other hand, was relatively fertile, namely ca. $50 \%$ of the pollen grains were stained with acetocarmine and they seemed to be viable. Seed fertility of $\left[\mathrm{NiR} \quad \mathrm{F}_{1}-3 \times R\right.$. sativus (cv. Horyo) $]-1$ plant is shown in Table 5 when the plant was pollinated by two cultivars of $R$. sativus. In this plant, seeds were obtained more successfully in open pollination than in backcrossing to $R$. sativus. In Table 6, these three progenies are described as OK, RR and OP lines of rasidh whose cytoplasm is substituted by that of B.nigra. In each line, more than half of the individual plants were euploid with $2 n=18$ showing regular meiosis. Twenty four plants were hyperploid with $2 n=19$ and they exhibited a consistent pairing type of $9 \mathrm{II}+1 \mathrm{I}$ at MI. Other aneuploids were $2 n=20,21$ and 22 with less pollen and lower seed fertility. Euploid plants reproduced predominantly euploids with stable chromosome configuration while the $2 n=19$ plants produced both euploids and hyperploids so far. Hypoploids were not obtained. Although amphiploid and sesquidiploid plants did not appear to be chlorophyll deficient, the three derived lines showed this unfavorable trait to some extent at seedling stage but chlorophyll deficiency in later growth was no longer present and the lines appeared to be normal. Via these lines, alloplasmic radishes have been bred in some representative cultivars of radish.

\section{Discussion}

Intergeneric hybridization between plants of the genus Raphanus and Brassica has been of great interest to cytogeneticists and plant breeders on account of the undefined genome relationship and its potential to increase the genetic diversity of the two genera. As for crosses of $R$. sativus ( $R$ genome) and three monogenomic Brassica species, viz. B.campestris (A genome), B.nigra (B genome) and B.oleracea (C genome), up to date, hybrid progenies have been bred in three cross combinations, i. e., R. sativus $\times$ B.oleracea, B.campestris $\times R$. sativus and B.oleracea $\times R$. sativus. However, to the authors' knowledge, the breeding of hybrid progenies between $R$. sativus and B.nigra had remained unsuccessful. The senior author confirmed the existence of strong barriers 
in both pre- and post-zygotic phases for fertilization and the hybrid embryos were so poorly developed as to require in vitro cultivation (MATsuzawa 1983). In the rearing of the hybrid $F_{1}$ plants, embryo culture technique was effective in $R$. sativus $\times$ B. nigra and three hybrids obtained previously were analyzed cytologically in the present study. In B.nigra $\times$ R.sativus, ovaryculture was more effective than embryo culture and 4 hybrids were obtained. The difference in effectiveness between these two techniques may be atributed to the specific cross-incompatibility between the two species and will require further studies.

Fukushima (1945) postulated that the allosyndetic pairings at M I between chromosome complements of $\mathrm{R}$ and $\mathrm{B}$ genomes may range from 3 to 5 since the maximum number of bivalents in " $\mathrm{R} \mathrm{BC}$ " hybrids is 9, on the assumption that " $\mathrm{R} C$ " hybrids exhibited 4 to 6 bivalent pairings and that there is no autosyndesis in $\mathrm{C}$ genome itself. Moreover by studying the meiotic chromosome behavior and observing the maximum 17 bivalents including 9 complete syndesis in two $\mathrm{C}$ genomes, it was estimated that the number of allosyndetic pairings between $\mathrm{R}$ and $\mathrm{B}$ genomes may range between 0 to 8 . In fact, the hybrid plants analyzed in the present study showed some kinds of pairings at MI irrespective to their autosyndetic or allosyndetic nature but trivalents and/or quadrivalents were not detected in either amphiploid or sesquidiploid plants. Kaneko (1980) reported that 35\% of the PMCs exhibited one to 3 autosyndetic pairings in haploid R.sativus. In haploid B.nigra, PRAKAsh (1976) observed one to 2 bivalents in autosyndetic pairings in $33 \%$ of the PMCs at MI. Considering these facts, it is likely that bivalent formation in the present ampiploid plants may be attributed to autosyndesis. Consequently the allosyndesis between $\mathrm{R}$ and $\mathrm{B}$ genomes may be less frequent than has been considered hitherto and the genetic recombination in these two genomes may rarely take place so as to increase the genetic diversity of Brassica crops.

Spontaneous occurrence of amphidiploids is not uncommon in interspecific and intergeneric hybridization of Brassica species (U 1935, Olsson 1960, Namai 1971) even when diploid male and female species are used in crosses. This phenomenon is ascribed to the union of unreduced gametes. An amphidiploid obtained in this study was reared presumably through this phenomenon. This amphiploid which yielded several seeds when pollinated by B.nigra and R. sativus failed to do so when used as a pollen parent. Assuming that the pollen of this amphiploid was fertile, it is likely that the cross-compatibility of pistil parents was associated with the insufficient development of hybrid seeds in crosses. Based on the same assumption, the fact that this amphiploid produced few seeds either in selfing or in open pollination may suggest the intrinsic manifestation of a distinct self-incompatibility which is prevailing in some members of Brassica.

The derived sesquidiploids also maintained their seed fertility to the extent of enabling the breeding of further generations when they were backcrossed to $R$. sativus. Resulting plants were euploid $(2 n=18)$ or hyperploid $(2 n=18+1-4)$ and did not form any multivalents at MI except for bivalents. The absence of hypoploid and the cytological studies performed in this generation made it possible to assume that the chromosome complement 
of the female gametes consisted of 9 chromosomes of the $\mathrm{R}$ genome supplemented with zero to 4 chromosomes of the $\mathrm{B}$ genome. In this regard, $2 n=19$ plants may be valuable materials to analyze the genetic potential of each choromosome of the B genome.

Kato and Tokumasu (1980) reported that Japanese radishes with B.japonica (A genome) cytoplasm suffered from chlorophyll deficiency. SArahima (1984) also reported the presence of severe chlorophyll deficiency in $R$. sativus with B.oleracea cytoplasm. The alloplasmic new lines bred in this study also showed moderate chlorophyll deficiency at the seedling stage but this defect was no longer detected in later growth. Some lines with only slight or no sign of this deficiency were bred in the next generation. Qualitative and quantitative evaluation of some agronomic characteristics is now in progress for further breeding work of Brassica crops in comparison with other kinds of alloplasmic radishes.

\section{Literature cited}

FUKUSHIMA, E. 1945. Cytogenetic studies on Brassica and Raphanus I. Studies on the intergeneric $\mathrm{F}_{1}$ hybrids between Brassica and Raphanus. J. Dept. Agric. Kyushu Imp. Univ. $7: 281 \sim 400$.

HARBERD, D. J. and E. D. MCARTHUR 1980. Meiotic analysis of some species and genus hybrids in the Brassiceae. In "Brassica crops and wild allies" TsunODA, S., K. HinATA and C. GOMEZ-CAMPO (eds.), Japan. Scientific Societies Press, Tokyo. 65 87.

INOMATA, N. 1977. Production of interspecific hybrids between Brassica campestris and B.oleracea by culture in vitro of excised ovaries I. Development of ovaries in various culture media with yeast extract and casein hydrolysate. Japan. J. Breed. $27: 295 \sim 304$.

KANEKO, Y. 1980. Haploid plants of Raphanus sativus. Chromosome Information Service 28: $21 \sim 23$.

KARPECHENKO, G. D. 1927. Polyploid hybrids of Raphanus sativus $\times$ Brassica oleracea L. Bull. Appl. Bot., Genet. P1. Breed. $17: 305 \sim 410$.

KATO, M. and S. TOKUMASU 1980. Nucleus substitution of Brassica japonica SIEB. with Raphanus satious L. and its resultant chlorophyll deficiency. Euphytica $29: 97 \sim 106$.

MATSUZAWA, Y. 1983. Studies on the interspecific and intergeneric crossability in Brassica and Raphanus. Special Bull. Coll. Agr. Utsunomiya Univ. $39: 1 \sim 86$.

NAMAI, H. 1971. Studies on the breeding of oil rape (Brassica napus var. oleifera) by means of interspecific crosses with the application of grafting method or the treatment of sugar solution. Japan. J. Breed. $21: 40 \sim 48$.

OLsSON, G. 1960. Species crosses within the genus Brassica II. Artificial napus L. Hereditas $46: 351 \sim 386$.

PRAKASH, S. 1973. Haploidy in Brassica nigra Koch. Euphytica 22 : 613 614.

SARASHIMA, M., Y. MATSUZAWA and T. KIMURA 1980. Intergeneric hybridization between Brassica oleracea and Raphanus sativus by embryo culture. EUCARPIA Cruciferae Newsletter $5: 25$.

1984. On the artificially induced plants in Brassica oleracea $\times$ Raphanus sativus V. $\mathrm{B}_{2} \mathrm{~F}_{2}$ plants. Japan. J. Breed. 34(Suppl.) : 66 67.

TERASAWA, Y. und N. SHIMOTOMAI 1928. Bastardierungsversuche bei Brassica und Raphanus. Sci. Rep. Tohoku Imp. Univ., Ser. N. No. $4: 827 \sim 841$.

TOKUMASU, S. 1976. The increase of seed fertility of Brassicoraphanus through cytological irregularity. Euphytica $25: 463 \sim 470$.

U, N. 1935. Genome-analysis in Brassica with special reference to the experimental formation of B.napus and peculiar mode of fertilization. Japan. J. Bot. $7: 389 \sim 452$.

WHITE;P. R. 1963. The cultivation of animal and plant cells. Ronald Press Co., new York. 


\section{ダイコンとクロガラシとの属間交雑と異質細胞質ダイコンの作出}

松澤康男・血嶋正 雄

（宇都宮大学農学部，宇都宮市，干321）

ダイコン (Raphanus sativus L., n=9) ×クロガラシ (Brassica nigra Kocн., n=8) とその逆交雑で, そ れぞれ肧及び子房培養法によって得られた雑種植物とその後代の細胞学的, 形態的な調查を行った。複半数性 $F_{1}$ 植物 $(2 \mathrm{n}=17)$ は，PMC の MI で (0 4) II+(9 17) I の染色体対合型を示し， 17 I 型のものが 57\%で 最も多く，ついで 1 II +15 I 型が約 $20 \%$ であった。また MII では，8ないし9個の染色体をもつ核が多かっ た。これらの植物の花色はダイコンと同じ白色であったが，他の形態は両親種の中間であった。また花粉稳性 は極めて低く，結莢も認められず，後代植物を得ることがでさなかった．

クロガラシメダイコンで得られた 1 個体の複二倍体 $\mathrm{F}_{1}$ 植物 $(2 \mathrm{n}=34)$ では, MI で $17 \mathrm{II}$ の形成がみられ (60\%)，また MII で 17 個の染色体をるつ核が多かった (92\%). この植物は, 複半数性のものに比べてより 巨大型であり，花色はやや黄白色を呈し，花粉稔性は高かった。この雑種個体を母親としてダイコン拉よびク ロガラシの花粉を交配して戻し交雑をしたところ，それぞれ BRR $(2 \mathrm{n}=26)$ 及び BBR $(2 \mathrm{n}=25)$ のゲノム組 成をもつ 2 基三倍体が得られた。これらの植物は，多くのPMCの MI でそれぞれ 9 II +8I 及び 8 II +9 I の対合型を示し，玉た MII では 12，13 岁るいは 14 個の染色体をもつ核が多く観察された。それらの植物 は，雑種 $\mathrm{F}_{1}$ 植物々同㥞に，多洒染色体を形成することがなく，したがってこれら雑種植物の染色体対合は同 親接合によるものと考光られた。

BRR 植物では，ダイコンの 2 品種との戻し交雑と放任受粉とで種子が得られたが，BBR 植物では得られな かった. BRR 植物の後代は, Table 6 に示すように OK, RR 特上び OP 系統とした。 3 系統の植物は, $2 \mathrm{n}$ =18 の正倍数体が最も多く (55\%)，それらの PMC の M 质び MII は正常であった. $2 \mathrm{n}=19$ 植物は, M I で 9 II +1 I の対合型を示し, また種子が得られた。. 正倍数体植物にダイコンの数品種を戻し交雑し，クロ ガラシの細胞質をもったダイコン系統を育成した．雑種 $\mathrm{F}_{1}$ および 2 基三倍体植物は葉緑素欠乏症状を示さな かったが，異質細胞質系統は生育初期に軽度ながらこの症状を示したししかし生育後期には回復するものが多 く，注ぼ正常と思われる植物子得られた。

今後, 得られた異質細胞質ダイコシの農業的形質を調查することにより,クロガラシの細胞質の比較評価が 可能になると考兄られる。 また，育成過程で得られた $2 \mathrm{n}=19$ 植物は, ダイコンの $R R(2 n=18)$ ゲノムにク ロガラシの染色体が添加した植物と思われ，Bゲノムのそれぞれの染色体の遗伝的解析の一助となると期待さ れる。 